\title{
Nowe przepisy dotyczące doświadczeń na zwierzętach. Najważniejsze zmiany i próba oceny
}

\author{
Krzysztof Smykowski \\ Wydział Teologiczny \\ Katolicki Uniwersytet Lubelski Jana Pawła II \\ Instytutu Teologii Moralnej, Al. Racławickie 14, 20-950 Lublin, krzysztof.smykowski@kul.pl
}

\begin{abstract}
Streszczenie
Ustawą z dnia 15 stycznia 2015 r. o ochronie zwierząt wykorzystywanych do celów naukowych lub edukacyjnych została wprowadzona w życie Dyrektywa Parlamentu Europejskiego i Rady z dnia 22 września 2010 r. w sprawie ochrony zwierząt wykorzystywanych do celów naukowych. Te akty prawne przyniosły szereg istotnych zmian dotyczących prowadzenia badań naukowych z wykorzystaniem zwierząt. Zostały sformułowane nowe definicje procedury i doświadczenia. Powiększono także zakres gatunków podlegających ochronie, rozszerzając go o głowonogi i embrionalne formy ssaków oraz wprowadzono całkiem nową skalę inwazyjności. Zmiany dotknęły także organy powołane do udzielania i zmian zgód na prowadzenie doświadczeń, czyli Krajową Komisję Etyczną do spraw Doświadczeń na Zwierzętach i lokalne komisje etyczne. Większość z nowych uregulowań należy przyjąć z zadowoleniem, ponieważ są realizacją słusznych postulatów ochrony zwierząt doświadczalnych.
\end{abstract}

\section{Stowa kluczowe}

eksperymenty na zwierzętach, komisje etyczne, prawo

\section{Wprowadzenie}

Dyrektywa Parlamentu Europejskiego i Rady $\mathrm{z}$ dnia 22 września $2010 \mathrm{r}$. w sprawie ochrony zwierząt wykorzystywanych do celów naukowych nałożyła na państwa członkowskie Unii Europejskiej nowe obowiązki w zakresie regulacji prawnych prowadzenia badań naukowych z wykorzystaniem zwierząt. W Polsce ustawodawca postanowił nie nowelizować dotychczas obowiązującej Ustawy z dnia 21 stycznia 2005 r. o doświadczeniach na zwierzętach, lecz zastąpił ją Ustawą $\mathrm{z}$ dnia 15 stycznia $2015 \mathrm{r}$. o ochronie zwierząt wykorzystywanych do celów naukowych lub edukacyjnych. Ten akt prawny nie tylko dokonuje implementacji Dyrektywy, lecz także wprowadza szereg istotnych zmian dotyczących zasad i organizacji wykonywania doświadczeń na zwierzętach. Jest ona efektem swego rodzaju kompromisu pomiędzy naukowcami a przedstawicielami organizacji filoanimalistycznych. W toku prac legislacyjnych obie grupy przedstawiały istotne zastrzeżenia dotyczące kolejnych projektów. $\mathrm{Z}$ jednej strony zarzucano, że nowe prawo może całkowicie uniemożliwić prowadzenie prac badawczych (Naukowcy apeluja o weto 2015: 2), z drugiej twierdzono, że może ono 
pozbawić organy państwowe i organizacje społeczne jakiejkolwiek kontroli nad procedurami eksperymentalnymi (Web-o1).

Celem niniejszego artykułu jest syntetyczne ukazanie wybranych zmian, które zaszły w polskim prawodawstwie na skutek wejścia w życie Ustawy o ochronie zwierząt wykorzystywanych do celów naukowych lub edukacyjnych oraz dokonanie ich oceny. Opierać się ona będzie na stwierdzeniu, na ile chroni ona dobra, do których zaliczyć należy wolność prowadzenia badań naukowych i możliwość osiągania postępu w nauce oraz słuszną ochronę zwierząt eksperymentalnych.

\section{Definicje}

Nowa ustawa nosi odmienny od poprzedniej tytuł. Ustawa o doświadczeniach na zwierzętach została zastąpiona przez Ustawę o ochronie zwierząt wykorzystywanych do celów naukowych lub edukacyjnych. Wydawać by się mogło, że w sposób istotny zwiększa ona zakres prawnego zabezpieczenia zwierząt laboratoryjnych, a kwestie zasad prowadzenia doświadczeń odkłada na drugi plan. Już jednak pobieżna lektura aktu prawnego pozwala stwierdzić, że sama struktura oraz jego przedmiot nie uległ poważniejszym zmianom, choć niektóre kwestie szczegółowe doczekały się daleko idących przekształceń.

Najbardziej rzucająca się w oczy zmiana dotyczy samej definicji doświadczenia. W myśl obowiązujących przepisów oznacza on już nie „każdą formę wykorzystania zwierzęcia do badań naukowych, testów i celów dydaktycznych, mogącą wywołać u niego ból, cierpienie, strach lub trwałe uszkodzenie w jego organizmie" (A: art. 2, p. 6). Doświadczeniem jest natomiast „program badawczy obejmujący procedurę lub procedury, mający określony cel naukowy lub edukacyjny" (F: art. 2, ust. 1, p. 7). Widać zatem wyraźnie, że nastąpiła znaczna zmiana rozumienia tego terminu, który oznacza już nie pojedynczą ingerencję, której poddawane jest zwierzę, lecz zespół działań mających precyzyjnie zdefiniowany cel.
Za sprawą nowych przepisów do ustawodawstwa weszło pojęcie procedury. Określa się tym mianem "każdą formę wykorzystania zwierząt [...], która może spowodować u zwierzęcia ból, cierpienie, dystres lub trwałe uszkodzenie organizmu, w stopniu równym ukłuciu igłą lub intensywniejszym" (F: art. 2, ust. 1, p. 6). Jak łatwo zauważyć, dotychczasowe doświadczenie jest obecnie zasadniczo określane jako procedura. Zaszła jednak przy tym jedna niewielka zmiana. Procedurę stanowi taka ingerencja, która dla zwierzęcia jest bardziej dokuczliwa niż ukłucie igłą. Ma to duże znaczenie praktyczne. Przepisom prawa nie podlegają odtąd działania mniej inwazyjne, na które prowadzący badania naukowe nie muszą uzyskiwać już zgody odpowiednich organów. Ma to na celu usprawnienie procesu oceny projektów badawczych i odciążenie instytucji je opiniujących.

Analizowana ustawa w sposób jednoznaczny do polskiego prawa wprowadza zasadę $3 \mathrm{R}$. Jest to reguła sformułowana w 1959 r. przez brytyjskich naukowców Wiliama M.S. Russella i Rexa L. Burcha, która określa podstawowe warunki etyczności doświadczeń z wykorzystaniem zwierząt. W jej świetle należy dołożyć wszelkich starań, by ograniczyć ilość zwierząt oraz odczuwany przez nie ból i stres, a także w miarę możliwości wykorzystywać alternatywne techniki (Smykowski 2015: 108). Choć już poprzednie regulacje w sposób pośredni odwoływały się do tych reguł (A: art. 20, ust. 4, p. 2), to jednak dopiero nowe przepisy wprost nakazują zastosowanie zasad zastąpienia, ograniczenia i udoskonalenia (F: art. 5, ust. 1, p. 1-3).

\section{Zakres ochrony zwierząt}

Ustawa rozszerza zakres gatunków zwierząt wykorzystywanych w celach naukowych i edukacyjnych, które podlegają ochronie. Przepisy z 2005 r. dotyczyły wyłącznie zwierząt kręgowych, a więc ryb, płazów, gadów, ptaków i ssaków oraz ich form larwalnych zdolnych do rozmnażania (A:art. 2, p. 1). Obecnie obowiązujące przepisy pod pojęciem zwierzęcia rozumieją także 
embrionalne formy ssaków w okresie ostatniej jednej trzeciej ich życia płodowego oraz żywe głowonogi (F: art. 2, p. 1). Rozciągnięcie ochrony jest odpowiedzią ustawodawcy na poznanie mechanizmu odczuwania bólu przez zwierzęta (C: (8)). Wykazano, że receptory bólowe występują na całym ciele głowonogów, a dobrze rozwinięty mózg pozwala im odczuwać bodźce związane ze zmianami temperatur, poziomem $\mathrm{pH}$ środowiska i uszkodzeniem tkanek (Lipiński 2009: 556-561). Takie uregulowanie należy przyjąć $\mathrm{z}$ zadowoleniem. Jest ono bowiem wyrazem troski o dobrostan zwierząt wykorzystywanych w eksperymentach.

Niewielkim zmianom uległa także możliwość wykorzystania poszczególnych grup zwierząt do określonych typów doświadczeń. Zasadą generalną jest, że w procedurach eksperymentalnych winne być używane przede wszystkim zwierzęta laboratoryjne, czyli organizmy, które są hodowane wyłącznie w celu prowadzenia na nich badań naukowych. Są to następujące gatunki: mysz domowa, szczur wędrowny, świnka morska, chomik syryjski, chomik chiński pręgowany, myszoskoczek mongolski, królik europejski, pies domowy, kot domowy, żaba trawna, żaba lamparcia, platana szponiasta, platana tropikalna i danio pręgowany (F: art. 2, ust. 1, p. 2; art. 7, ust. 1, p. 1; Radecki 2015: 291). Gdy wykorzystanie tej grupy nie jest możliwe dla osiągnięcia założonych celów, można dopiero sięgnąć po przedstawicieli innych gatunków.

Ustawa formułuje także zakazy wykorzystania pewnych grup zwierząt w procedurach. Bezwzględny zakaz dotyczy małp człekokształtnych, czyli goryli, szympansów i orangutanów (F: art. 8, ust. 1, p. 1; Radecki 2015: 293). Zakazem względnym objęte zostały dwie grupy zwierząt. Co do zasady niemożliwe jest prowadzenia badań na zwierzętach bezdomnych, czyli zwierzętach domowych, które uciekły lub zostały porzucone i nie istnieje możliwość ustalenia ich właściciela (Radecki 2015: 293). Istnieje jednak jeden wyjątek. Dopuszczalne są procedury mające służyć zbadaniu ich zdrowia i dobrostanu oraz przeciwdziałaniu zagrożeniom dla zdrowia człowieka i innych zwierząt oraz negatywnym wpływom na środowisko (F: art. 8, ust. 2, p. 2). W nowej Ustawie nastąpiła zatem liberalizacja tego przepisu. Dotychczasowe regulacje utrzymywały bowiem bezwzględny zakaz eksperymentowania na zwierzętach bezdomnych (A: art. 7, ust. 2; Radecki 2007: 206). Wskazuje się jednakże, że taka regulacja może być sprzeczna z ustawowym określeniem dopuszczalnych celów prowadzenia badań (F: art. 3).

Względny zakaz dotyczy także zwierząt dzikich. Ich wykorzystanie jest możliwe, jeśli celów doświadczenia nie można osiągnąć przy pomocy zwierząt laboratoryjnych lub wymienionych powyżej gatunków (F: art. 8, ust 2, p. 1; Malinowska 2015a: 359). Wprowadzenie tych przepisów spotkało się ze znacznym oporem środowiska naukowców. Argumentowali oni, że ograniczą one prace w ramach szeroko pojętej biologii środowiskowej, w tym prowadzące do rozwiązania najgroźniejszych współczesnych problemów ekologicznych (Naukowcy apeluja o weto 2015: 2-3). Zdaniem znawców prawa te obawy są jednak bezpodstawne. Jedynym warunkiem wyrażenia zgody na tego rodzaju prace badawcze jest bowiem wykazanie, że celu nie można uzyskać przy pomocy zwierząt laboratoryjnych (Radecki 2015: 293).

\section{Skala inwazyjności}

Daleko idące zmiany dotknęły skalę inwazyjności stosowaną przy ocenie procedur badawczych. Dotychczas obowiązywała skala pięciostopniowa oparta na kategoriach inwazyjności wypracowanych w amerykańskich, australijskich i nowozelandzkich ośrodkach naukowych wprowadzona uchwałą Krajowej Komisji Etycznej do spraw Doświadczeń na Zwierzętach (Mroczkowski 2001: 1). Niewątpliwym walorem nowych przepisów jest ustawowe umocowanie nowej skali inwazyjności (F: art. 10, ust. 1-2). Do tej pory miała bowiem ona jedynie rangę zalecenia wydanego przez nadrzędny organ, jakim jest Krajowa Komisja Etyczna. 
Nowa skala inwazyjności w sposób istotny różni się od dotychczasowej. Opiera się na podziale procedur na terminalne bez odzyskania przytomności przez zwierzę, łagodne, umiarkowane i dotkliwe. Pierwsza grupa obejmuje wszystkie te ingerencje, które przeprowadzane są w znieczuleniu ogólnym, a po ich zakończeniu zwierzę jest uśmiercane. Według starych przepisów tego rodzaju badania zaliczone były do drugiego stopnia skali inwazyjności. Drugi stopień stanowią procedury łagodne, w których zwierzęta mogą odczuwać krótki, łagodny ból lub dystres. Mogą także one wywoływać nieznaczny wpływ na stan ogólny. Trzecią grupą są procedury umiarkowane. Powodują krótki, umiarkowany lub długotrwały, łagodny ból i stres. W sposób umiarkowany wpływają także na ogólną kondycję. Ostatnią grupą są doświadczenia, które oddziałują dotkliwie na stan ogólny lub powodują znaczny, często długotrwały ból i stres (F: art. 10, ust. 1-2; Radecki 2015: 294-298). Wykaz przykładowych procedur zaliczonych do poszczególnych kategorii zamieszczony jest w dyrektywie, do której wprost odsyła ustawa (C: Załącznik 8).

Nowa skala nie uwzględnia dotychczasowego pierwszego stopnia, czyli doświadczeń nieinwazyjnych, w których żadne zwierzę nie jest narażone na cierpienie lub jakikolwiek uszczerbek. Do tego typu kwalifikuje się większość badań hodowlanych, żywieniowych i zootechnicznych, a zgoda lokalnych komisji etycznych była w tym wypadku czystą formalnością (Mroczkowski 2001: 1). Jak już to zostało zasygnalizowane, obecna definicja procedury nie obejmuje bowiem działań powodujących mniejszy ból i stres niż ukłucie igłą. Tę zmianę należy przyjąć z uznaniem.

Został wyeliminowany także dotychczasowy stopień X, który obejmował niedopuszczalne procedury powodujące skrajne cierpienie. Ich wykonywanie było możliwe jedynie wtedy, gdy wprost domagało się tego obowiązujące prawo, a zgoda nie mogła być wyrażona przez organ pierwszego stopnia, czyli przez lokalne komisje etyczne.
Tego typu wniosek zawsze opiniowany był przez Krajową Komisję Etyczną (Mroczkowski 2001: 1-2). Niektóre procedury zakwalifikowane dotychczas do stopnia X zostały uznane za procedury dotkliwe. Przykładem są chociażby badania toksyczności, w których za punkt końcowy uznaje się śmierć zwierzęcia lub oczekuje się, że nastąpią śmiertelne przypadki i dotkliwe stany patofizjologiczne. Wydaje się, że ze względu na dobrostan zwierząt i słuszne postulaty ich ochrony celowe byłoby utrzymanie specjalnego statusu tych najpoważniejszych procedur. W ten sposób do polskiego systemu prawnego weszły przepisy będące swego rodzaju krokiem wstecz wobec dotychczasowych uregulowań.

Zakwalifikowanie projektu badawczego do kategorii dotkliwej wiąże się z koniecznością dokonania przez komisję oceny retrospektywnej doświadczenia. Polega ona na przeanalizowaniu zrealizowania celów eksperymentu i poprawności kwalifikacji poszczególnych procedur do odpowiedniej kategorii. Przedmiotem refleksji są także wnioski, które mogą przyczyniać się do wdrażania zasad $3 R$. Przesłanką przeprowadzenia oceny jest także wykorzystanie $\mathrm{w}$ badaniach zwierząt z rzędu naczelnych. Komisja może także fakultatywnie zarządzić ją w przypadku dużej ilości zwierząt poddanych testom lub ze względu na zaplanowane cele. (F: art. 53; Radecki 2015: 355).

\section{Komisje etyczne i nadzór społeczny}

Wykorzystywanie zwierząt w celach naukowych i edukacyjnych zostało przez ustawodawcę poddane monitorowaniu w dwojakiej formie. Pierwszą z nich jest wymiar instytucjonalny, który obejmuje działalność Krajowej Komisji Etycznej do spraw Doświadczeń na Zwierzętach i lokalnych komisji etycznych oraz Głównego Lekarza Weterynarii. Niemniej istotna jest kontrola społeczna prowadzona przez organizacje pozarządowe, których statutowym celem jest ochrona zwierząt. Duże znaczenie ma także podawanie do publicznej wiadomości podstawowych informacji dotyczących 
ilości wykonanych doświadczeń i zwierząt im poddanych.

Spośród wymienionych instytucji omówiona zostanie działalność komisji etycznych. Ich rola jest bowiem najbardziej doniosła. Ponadto Ustawa o ochronie zwierząt wykorzystywanych do celów naukowych lub edukacyjnych wprowadziła w tych gremiach poważne zmiany. Nowe lokalne komisje etyczne zostały powołane przez Ministra Nauki i Szkolnictwa Wyższego. Zastąpiły one dotychczasowe komisje międzyuczelniane, międzyinstytutowe i wspólne (Mroczkowski, Frieske 2013: 354). Do jedenastu została także zredukowana ich ilość. Precyzyjnie określona jest także obecnie właściwość miejscowa poszczególnych komisji. Ich działalność obejmuje w większości przypadków jedno, dwa lub trzy województwa. Tylko województwach mazowieckim i małopolskim ze względu na dużą ilość zakładów doświadczalnych powołane zostały dwie komisje. Ich właściwość miejscowa jest także precyzyjnie określona i obejmuje wskazane w Rozporządzeniu dzielnice lub powiaty (G: Załącznik nr 2).

Poważne zmiany dotknęły także skład lokalnych komisji etycznych. Do 2015 r. zasiadało $\mathrm{w}$ nich pięciu przedstawicieli nauk biologicznych, medycznych, rolniczych, weterynaryjnych i humanistycznych oraz dwóch reprezentantów organizacji pozarządowych, których celem jest ochrona zwierząt (B: art. 30, ust. 2). Łatwo zauważyć zatem, że środowisko nauk eksperymentalnych posiadało bezwzględną większość, co w praktyce umożliwiało mu samodzielne podejmowanie decyzji dotyczących wyrażenia zgody na rozpoczęcie procesu badawczego.

Struktura nowych lokalnych komisji etycznych jest zgoła inna. Liczą one dwunastu członków, spośród których połowa jest przedstawicielami nauk biologicznych, farmaceutycznych, medycznych, rolniczych lub weterynaryjnych. Trzech członków reprezentuje nauki społeczne i humanistyczne, w tym przede wszystkim prawo, etykę lub filozofię. Jeden z nich jest ponadto delegatem organizacji, której celem jest ochrona praw pacjenta. Trzech przedstawicieli mają także organizacje filoanimalistyczne (F: art. 37, ust. 1, p. 1-3). W praktyce oznacza to, że w strukturze komisji działa siedmiu członków reprezentujących środowiska zainteresowane maksymalną wolnością prowadzenia badań (przedstawiciele nauk ścisłych i organizacji działających na rzecz praw pacjenta), trzech dążących do ograniczenia ilości doświadczeń (członkowie stowarzyszeń na rzecz ochrony zwierząt) i dwóch niezależnych (przedstawiciele nauk humanistycznych i społecznych). W pierwotnej wersji ustawy członków niezależnych miało być trzech. Na skutek konsultacji międzyresortowych i społecznych ich liczbę zmniejszono do dwóch (Web-02). Większa ilość osób niezainteresowanych wprost procesem doświadczalnym z całą pewnością wpłynęłaby pozytywnie na bezstronność decyzji podejmowanych przez komisję. Krajowa Komisja Etyczna od 2015 r. liczy piętnastu członków, z których dziewięciu reprezentuje nauki ścisłe, trzech dziedziny społeczne i humanistyczne, a trzech organizacje chroniące zwierzęta (F: art. 34, ust. 1, p. 1-3).

Zmiany dotknęły także sposobu wyłaniania członów Krajowej Komisji Etycznej i Lokalnych Komisji Etycznych. Do 2015 r. kandydaci mogli być oni zgłaszani jedynie przez uniwersytety, akademie medyczne, wyższe szkoły rolnicze, akademie wychowania fizycznego, Polską Akademię Nauk, laboratoria weterynaryjne, wytwórnie produktów leczniczych, jednostki organizacyjne posiadające specjalistyczne laboratoria oraz organizacje pozarządowe, których statutowym celem działania jest ochrona zwierząt $(\mathrm{B}: \mathbb{S} 2)$. Obecnie swoją kandydaturę składa sama osoba zainteresowana (nie dotyczy to oczywiście przedstawicieli organizacji ochrony zwierząt i praw pacjenta). Nie musi ona posiadać rekomendacji żadnej z wyżej przywołanych instytucji, a jedyną przesłanką decydującą o powołaniu w skład komisji jest ocena wiedzy, umiejętności i dorobku naukowego (G: $\$$ 2-6). Z całą pewnością ta zmiana pozwala na otwarcie bardzo hermetycznego środowiska, jakim były komisje 
etyczne, na szerokie grono osób posiadających odpowiednie kwalifikacje. Warto by jednak zatroszczyć się o lepszy sposób informacji potencjalnych kandydatów o rekrutacji. Nabór do większości z nowych komisji musiał bowiem zostać przedłużony z uwagi na niedostatek kandydatów reprezentujących nauki humanistyczne i społeczne oraz stowarzyszenia działające na rzecz ochrony praw pacjenta (Web-o3).

Doniosła zmiana dotyczy także sposobu podejmowania uchwał przez lokalne komisje etyczne. Zgoda na wykonanie procedury jest wyrażana większością dwóch trzecich głosów w obecności co najmniej połowy członków (F: art. 48, ust. 5). Także ten przepis spotkał się z dużą krytyką ze strony środowiska naukowców. Podnieśli oni zarzut, że nastąpi całkowity paraliż prac badawczych na skutek tego, że połowa składu lokalnej komisji ma się rekrutować z ze środowisk, które podważają zasadność wykonywania doświadczeń na zwierzętach (Naukowcy apeluja o weto 2015: 2). Takie twierdzenia były oczywistą manipulacją, a nowy przepis należy ocenić jednoznacznie pozytywnie. Konieczność uzyskania ośmiu głosów poparcia z jednej strony nie pozwala podjąć pozytywnej decyzji wyłącznie osobom zainteresowanym prowadzeniem badań (naukowcom i reprezentantowi organizacji praw pacjenta), a drugiej wyklucza możliwość zablokowania prac tylko przez członków stowarzyszeń filoanimalistycznych. Podobna sytuacja ma miejsce przy rozpatrywaniu odwołania przez Krajową Komisję Etyczną, gdzie konieczne jest pozyskanie przynajmniej jednego głosu poparcia ze strony reprezentantów nauk humanistycznych i społecznych lub organizacji ochronnych (Radecki 2015: 348).

Ustawa gwarantuje wszystkim członkom komisji całkowitą niezależność (F: art. 38, ust. 1). Oznacza to, że żaden organ administracji publicznej, hodowca, dostawca czy użytkownik nie może wydawać członkowi komisji poleceń i w jakikolwiek sposób wpływać na ich działania (Radecki 2015: 335). Dotyczy to także organizacji prozwierzęcych, które oddelegowały swoich przedstawicieli do składu komisji. W toku prac legislacyjnych walczyły one o możliwość odwoływania swych reprezentantów i desygnowania nowych (Web-o1). Umożliwienie takiego działania nosiłoby jednak znamię nadmiernej ingerencji i stawiałoby pod znakiem zapytania niezależność i bezstronność członków komisji etycznych.

Nadzór społeczny realizowany jest przez publikowanie informacji o liczbie wykonanych doświadczeń. Obowiązek ten wprowadziła Ustawa o doświadczeniach na zwierzętach (A: art. 37, ust. 1). Obecne przepisy przyniosły niewielkie zmiany. To coroczne sprawozdanie ma być od tej pory udostępniane przez ministra właściwego do spraw nauki do 31 sierpnia na stronie internetowej Biuletynu Informacji Publicznej, a nie jak do tej pory do 30 czerwca. Została tym samym obniżona ranga tego dokumentu, który wcześniej miał rangę obwieszczenia (F: art. 33, ust. 6; art. 65 Malinowska 2015b: 564). Pozostaje wyrazić nadzieję, że obowiązek ten będzie ściśle realizowany. Dotychczasowa praktyka pozostawia bowiem wiele do życzenia. Raport za 2011 r. ogłoszony został 18 października 2012 r. (D), a za 2013 r. 27 sierpnia 2014 r. (E).

\section{Zakończenie}

Ustawa z dnia 15 stycznia $2015 \mathrm{r}$. o ochronie zwierząt wykorzystywanych do celów naukowych lub edukacyjnych i szereg jej aktów wykonawczych wprowadziły znaczne zmiany w zakresie prowadzenia doświadczeń i prac badawczych z wykorzystaniem zwierząt. Do najważniejszych z nich zaliczyć należy sformułowanie nowych definicji procedury i doświadczenia oraz wprowadzenie do polskiego systemu prawnego zasady 3 R. Niemniej istotne są przemiany w składzie i zasadach pracy gremiów, które wyrażają zgodę na wykonanie eksperymentów oraz je nadzorują. Nowe przepisy gwarantują szerszą społeczną reprezentację w tych komisjach oraz skłaniają ich członków do poszukiwania konsensusu, który zakłada poszanowanie zarówno interesów 
środowisk naukowych, jak i słusznych postulatów ochrony zwierząt. Większość zmian należy ocenić pozytywnie, choć nie brakuje też uwag krytycznych pod adresem niektórych przepisów szczegółowych. Nowe przepisy stosunkowo niedawno weszły w życie, gremia oceniające i kontrolujące są na etapie powoływania lub dopiero rozpoczynają swoją pracę. Upłynie zatem jeszcze kilka lat, zanim w pełni będzie można dokonać oceny wszystkich skutków zmienionych regulacji prawnych.

\section{Bibliografia}

Lipiński M.R., 2009, Gromada: głowonogi-Cephalopoda, w: Błaszak Cz. (red.), „Zoologia. Bezkręgowce", vol. 1, Wydawnictwo Naukowe PWN, Warszawa, 553-596.

Malinowska T., 2015a, Doświadczenia i procedury z wykorzystaniem zwierzat w nowych regulacjach prawnych, Życie Weterynaryjne, vol. 6, 358-360.

Malinowska T., 2015b, Nadzór i kontrola doświadczeń $i$ procedur $z$ wykorzystaniem zwierzat $w$ nowych regulacjach prawnych, Życie Weterynaryjne, vol. 9, 562-565.

Mroczkowski S., 2001, Komisje etyczne do spraw doświadczeń na zwierzętach, Przegląd Hodowlany, vol. 1, 1-2.

Mroczkowski S., Frieske A., 2013, Lokalne komisje etyczne do spraw doświadczeń na zwierzętach, Medycyna Weterynaryjna, vol. 6, 353-357.

Naukowcy apeluja o weto, 2015, Panorama Polskiej Akademii Nauk, vol. 3, 2-3.

Radecki W., 2007, Ustawy: o ochronie zwierzat, o doświadczeniach na zwierzętach - z komentarzem, Difin, Warszawa.

Radecki W., 2015, Ustawy o ochronie zwierzat. Komentarz, Difin, Warszawa.

Smykowski K., The Possibility of Conducting Experiments of Animals. Moral Theologian's Reflections, Studia Ecologiae et Bioethicae, vol. 2, 107-119.

(Web-01) Siedlecka E., Doświadczenia na zwierzętach: czy zawsze interes człowieka jest najważniejszy?, <http://wyborcza.pl/1,75968,16875842,Doswiadczenia_na_zwierzetach__czy_zawsze_interes_ czlowieka.html>, dostęp: 15.1.2016.

(Web-02) Kolarska-Bobińska L., Do osób i organizacji zainteresowanych ustawa o ochronie zwierzat wykorzystywanych do celów naukowych i edukacyjnych, <http://www.nauka.gov.pl/g2/ oryginal/2014_12/bd0d3eaf573d35c5befc8d9a8d46956f.pdf >, dostęp: 19.1.2016.

(Web-03) Ogtoszenie o przedtużeniu naboru kandydatów na członków Lokalnych Komisji Etycznych do Spraw Doświadczeń na Zwierzętach, <http:// www.bip.nauka.gov.pl/przedluzenie-naboru-kandydatow-na-czlonkow-lokalnych-komisji-etycznych-do-spraw-doswiadczen-na-zwierzetach>, dostęp: 5.1.2016.

A. Ustawa z dnia 21 stycznia 2005 r. o doświadczeniach na zwierzętach. (Dz.U.2005.33.289 z dnia 24 lutego 2005 r.).

B. Rozporządzenie Ministra Nauki i Informatyzacji z dnia 29 lipca 2005 r. w sprawie Krajowej Komisji Etycznej do Spraw Doświadczeń na Zwierzętach oraz lokalnych komisji etycznych do spraw doświadczeń na zwierzętach. (Dz.U.2005.153.1275 z dnia 12 sierpnia 2005 r.).

C. Dyrektywa Parlamentu Europejskiego i Rady z dnia 22 września 2010 r. w sprawie ochrony zwierząt wykorzystywanych do celów naukowych. (Dz.Urz.UE.2010.276 z dnia 20 października 2010 r.).

D. Obwieszczenie Ministra Nauki i Szkolnictwa Wyższego z dnia 18 października 2012 r. w sprawie raportu o liczbie zwierząt wykorzystanych do celów doświadczalnych w 2011 r. i stopniu inwazyjności przeprowadzonych doświadczeń. (Dz.Urz.MNiSW.2012.71 z dnia 10 grudnia 2012 r.).

E. Obwieszczenie Ministra Nauki i Szkolnictwa Wyższego z dnia z dnia 27 sierpnia 2014 r. w sprawie raportu o liczbie zwierząt wykorzystanych do celów doświadczalnych w 2013 r. i stopniu inwazyjności przeprowadzonych doświadczeń. (Dz.Urz.MNiSW.2014.49 z dnia 3 września 2014 r.).

F. Ustawa z dnia 15 stycznia 2015 r. o ochronie zwierząt wykorzystywanych do celów naukowych lub edukacyjnych. (Dz.U.2015.266 z dnia 26 lutego 2015 r.).

G. Rozporządzenie Ministra Nauki i Szkolnictwa Wyższego z dnia 5 maja 2015 r. w sprawie Krajowej Komisji Etycznej do Spraw Doświadczeń na Zwierzętach oraz lokalnych komisji etycznych do spraw doświadczeń na zwierzętach. (Dz.U.2015.630 z dnia 8 maja 2015 r.). 
New Provisions Concerning Animal Experiments.

The Most Important Changes and an Attempt of Assessment

\section{Summary}

Act of 15 January 2015 on protection of animals used for scientific and educational purposes implemented Directive of the European Parliament and of the Council of 22 September 2010 on protection of animals used for scientific purposes. The above legal acts have led to a number of changes concerning the conduct of scientific research with the use of animals. New definitions of the procedure and experiments were formed. Moreover, the range of species subject to protection was expanded by cephalopods and foetal forms of mammals. A completely new scale of invasiveness was implemented. The changes also affected regulatory bodies, namely, the National Ethics Committee for Animal Experiments as well as local ethics committees The majority of new provisions should be accepted with satisfaction, because they constitute an enforcement of the right proposals concerning the protection of test animals.

\section{Keywords}

ethical committees, experiments on animals, law 